\title{
Measuring the Effectiveness of National Enforcers in the IFRS Context: A Proactive Approach
}

\author{
Alberto Quagli ${ }^{1}$, Francesco Avallone ${ }^{1}$, Paola Ramassa ${ }^{1} \&$ Lorenzo Motta $^{1}$ \\ ${ }^{1}$ Department of Economics and Business Studies, University of Genoa, Italy \\ Correspondence: Paola Ramassa Department of Economics and Business Studies, University of Genoa, Italy.
}

Received: March 23, 2018

Accepted: May 4, $2018 \quad$ Online Published: May 18, 2018

doi:10.5539/ibr.v11n6p151

URL: https://doi.org/10.5539/ibr.v11n6p151

\begin{abstract}
It is widely acknowledged that an effective enforcement system represents a crucial element to achieve significant improvements in financial reporting through the adoption of high-quality accounting standards. Indeed, the quality of financial reporting is considerably influenced not only by the standards to be adopted but also by their actual implementation, and consequently by enforcement mechanisms.

The topic has generated considerable interest among scholars, who devoted their attention to developing different measures of the quality of the enforcement system. Building upon this literature, this paper aims at exploring the accounting enforcement system and focuses on controls over financial reporting considering two levels, namely the auditing activity and the controls performed by national enforcers.

This paper extends the prior literature by proposing a dynamic measure of the accounting enforcement system capturing controls at those two levels. More specifically, the index here proposed focuses on the quality of the accounting enforcement operated by national enforcers in terms of proactivity, intended as the national enforcers' capability to detect problems not highlighted in the auditors' opinions, thus shifting the focus from an input to an output perspective. Indeed, the activities of auditors and national enforcers are strictly connected, given that the auditors' opinion is the first public output of accounting controls and that is normally one of the bases for further investigation by national enforcers. An illustrative empirical analysis is carried out on the German and the Italian contexts to show the potential of the index for enforcement studies.
\end{abstract}

Keywords: accounting enforcement, financial reporting, IFRS, Europe, auditing, enforcement measures

\section{Introduction}

The relevance of the enforcement system in influencing accounting quality has received growing interest in the academic literature. Evidence suggests that the simple adoption of high-quality standards, such as IFRS, is not sufficient to increase homogeneously the quality of the accounting numbers resulting from those standards, and the accounting enforcement has a relevant influence on the phenomenon.

The accounting enforcement for publicly listed companies is a complex system where several subjects interact (Quagli \& Ramassa, 2017). We can identify two subsystems (Figure 1): the company level and the external one. Within the company level, many subjects can be involved on accounting topics, including the internal auditor, the audit committee inside the board, up to the general shareholders meeting that approves the financial reports prepared by the CEO and the CFO. At a company level, the external auditor operates as a fundamental link between the internal level and the external one, considering that the external auditor informs public enforcers about any weakness found during his work. The external subsystem is based on the activity of the national enforcer, able to enforce accounting errors and frauds by imposing the restatement of financial reports, giving sanctions to companies and managers, and activating courts for the most serious cases. Press and public opinion, as well as financial markets, use information from those subjects to penalize companies for their misreporting. In some jurisdictions (i.e. the US) private enforcers are very active subjects as well, originating private litigations to defend the investors' interests against the company managers responsible for accounting errors.

This depicted system has specific features depending on the country. In particular, for the European countries, it is worth noting that ESMA operates a supra-national coordination of national enforcers following the EU decision of mandatory IFRS adoption in the consolidated financial statements of the EU listed companies. In a strict sense, the most acknowledged enforcers are the national enforcers, as they have the legal authority to give 
sanctions and impose corrections and restatements of the financial information disclosed to markets. In this perspective, auditors do not have a similar power, since they can only signal to markets the errors observed in their review. However, markets generally perceive qualified or negative auditors' opinions as a risk increase on the company, with consequent negative reactions (Chen et al., 2000; Menon \& Williams, 2010). Therefore, auditors can be deemed as "substantial" enforcers (Chen et al., 2000), being on the front line to ensure high-quality financial reporting (FEE, 2001).

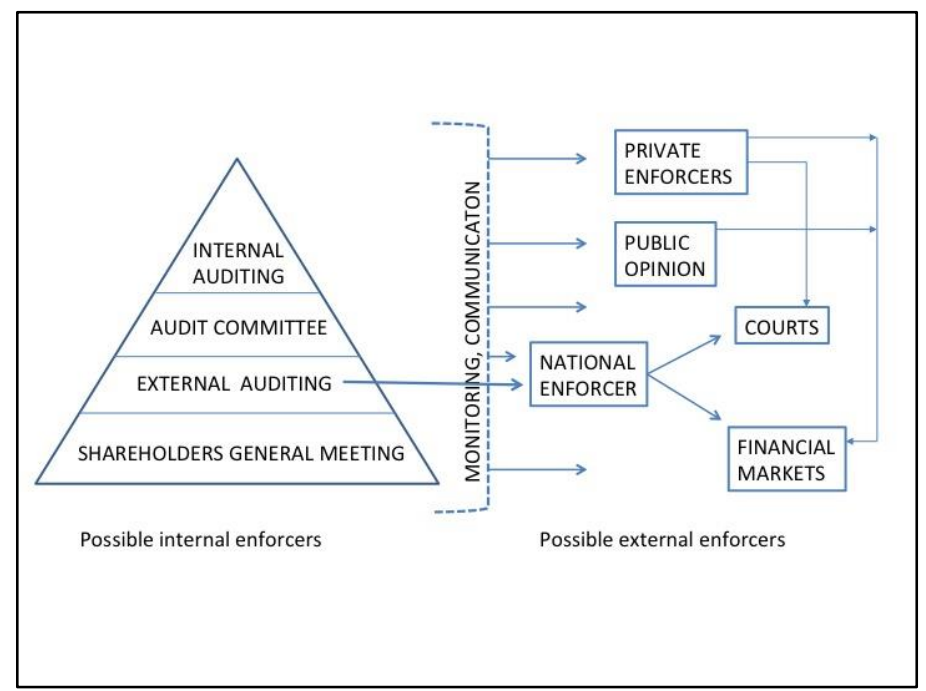

Figure 1. The accounting enforcement system (Source: Quagli \& Ramassa, 2017)

Accounting enforcement can originate many processes, composed of different steps and involving more than a single subject (Figure 1). The possible situations are various, for instance the triggering events of an enforcement activity can be located at an external level (i.e. a decision of the national enforcer can originate both private enforcement activity and court lawsuits) or at an internal level (i.e. the auditor's opinion can inform audit committees and shareholders and deny the approval of financial statements in their meetings).

The relationship between the national enforcer and the auditors is a relevant link in the enforcement system. The ESMA Guideline 5 (ESMA, 2014) deals with the selection criteria for the regular monitoring activity of the national enforcer and establishes that the enforcer's selection model "should be based on a mixed model whereby a risk-based approach is combined with a sampling and/or a rotation approach". The guideline specifies that the risk approach implies "indications from the auditors of misstatements, whether in their reports or otherwise, will normally trigger a selection of the financial information in question for examination. Indications of misstatements provided by auditors or regulatory bodies as well as grounded complaints should be considered for enforcement examinations. On the other hand, an unqualified opinion from an auditor should not be considered as proving the absence of risk of a misstatement. Enforcement examinations should be considered where, after preliminary scrutiny, a complaint received appears reliable and relevant for a possible enforcement examination."

In this context, one of the most difficult challenges for researchers on this topic is to develop relevant measures for the intensity of enforcement in a country, to be used in comparisons among countries and to evaluate the influence of the enforcement system on accounting quality at an aggregate level. Within this complex system, many papers focused on the activity of single subjects but they suffer the lack of data on the outputs of the most relevant enforcers, the auditors, and the national enforcers. Such limitations imply that detailed analyses of national enforcement systems deal only with countries with publicly available data (i.e. the US and Germany).

This paper proposes a new kind of measure, the national enforcers' proactivity (NEP) ratio, based on the unexplored relationship between national public enforcer and companies' auditors. This focus allows adding a dynamic perspective to scrutinize the enforcement process whereas the extant literature mainly uses a static analysis, often focused on a single subject. In particular, the index here proposed is determined as the percentage of accounting enforcement actions adopted by the national enforcer that do not regard financial statements that received qualified or negative opinions by the auditors. This index can help researchers to catch the effectiveness of national enforcers in terms of proactivity, measured by enforcement actions based on their own initiative (without being prompted by auditors). In such a perspective, it can support studies aimed at exploring whether - 
and to what extent - national public enforcers use auditors' opinion as a major input of their activity or, alternatively, their enforcement decisions are proactive respect to the auditor's work.

The index can also allow a comparison of the effectiveness of national enforcers between countries if we posit that the monitoring activity performed by auditors is less affected by country differences. This proposal, in other words, is based on the idea that the effectiveness of national enforcers can be measured by observing the number of enforcement proactive actions not previously "suggested" by auditors with their opinions on the companies' reports.

An illustrative empirical analysis is then carried out to show the potential of the index for enforcement studies. In particular, the exploratory analysis investigates the enforcement actions by the German and the Italian enforcers regarding consolidated financial statements of listed companies from the first year of IFRS mandatory adoption. Findings highlight a different degree of proactivity between the Italian and the German enforcers, with a higher ability of the German one to conduct autonomous analyses resulting in enforcement actions. Empirical evidence suggests that the Italian authority is more reactive in monitoring listed companies, relying more on auditors' opinions instead of pursuing new investigations.

This study contributes to enforcement literature as it sheds light on the enforcement process and the links between key actors favoring a dynamic perspective. Additionally, our findings have relevant policy implications as they allow an evaluation of the role played by public enforcers and auditors in terms of errors undetected by the latter and found by the formers.

The remainder of the paper is organized as follows. The next section discusses prior literature on the enforcement system, its effects on financial reporting and markets, as well as the measures of their intensity. The development of the NEP index is explained in section 3, and section 4 illustrates the research design of the illustrative empirical analysis conducted on the enforcement systems adopted in Germany and Italy. Section 5 presents the findings, and section 6 provides concluding comments and some implications for future research.

\section{Literature Review}

The relevance of the enforcement system in influencing accounting quality has received growing interest in the academic literature. This interest increased since the worldwide adoption of the IFRS, deemed as high-quality standards, does not seem sufficient to increase homogeneously the quality of the accounting numbers resulting from those standards. From the first studies on the international comparisons of accounting quality (Ball et al., 2000; Ball et al., 2003), an impressive number of papers demonstrated in a IFRS context how cost of capital, liquidity, and others measures of financial markets efficiency, basically depend on the enforcement intensity existing in the different countries (Daske et al. 2008; Armstrong et al., 2010; Li, 2010; Landsman et al., 2012; Christensen et al. 2013; Silvers, 2013). When the enforcement system is stronger, also financial analysts' estimates are more accurate (Byard et al., 2011; Demmer et al. 2015; Preiato et al., 2015), the institutional investors' ownership increase (Florou \& Pope, 2012), and earnings management behaviours decrease (Cai et al., 2008; Houqe et al. 2012). Finally, in countries with a stronger enforcement, financial disclosure improves as well (Glaum et al., 2013; Gros \& Koch, 2015). From all those studies, the importance of the enforcement system clearly emerges. Notwithstanding, this literature has to deal with the challenging measure of the intensity of the accounting enforcement system "to capture differences in enforcement between countries and changes in enforcement within a country over time" (Brown et al., 2014). The interest for the topic favored a rapid sophistication in the soundness of measures.

At the beginning, many of those studies used "static" proxies for this relevant variable, mainly the index originally proposed by La Porta et al., 1997 and La Porta et al., 1998 (used by Hope, 2003, and Leuz et al. 2003), who ranked a group of countries based on the level of investor's protection as resulting from the business community evaluations (i.e. strong rule of law, judicial system efficiency, degree of corruption, specific legal rules to protect creditors and minorities) or the opinions of actors of the national judicial system (La Porta et al., 2006). With a similar static approach, another more recent and comprehensive index rather used in accounting studies is the World Bank's corporate governance ranking of 215 countries (Kaufmann et al., 2011, for example, used by Daske, 2008, and Pownall \& Wieczynska, 2013). This stream of studies has also tried to overcome the criticism of measures based only on the "law-on-the-books" by proposing a ranking derived from an international survey to courts aimed at catching the variety of national enforcement system approaches in front of simulated lawsuits (Djankov et al., 2008). This "static" stream evolved to measure the national enforcement intensity considering how the EU countries actually adopted the CESR best practices for the monitoring of financial markets (CESR, 2007, used by Van Beest et al., 2013). A more recent trend of studies tried to measure more specifically the accounting enforcement system, instead of the general indexes of investor protection or 
corporate governance. Christensen et al. (2013) used the creation of a specific national accounting enforcer after the EU mandatory adoption in 2005 as a proxy of the enforcement intensity (used also in Pownall \& Wieczynska, 2013; Silvers, 2013).

On the other side, a more dynamic approach to the definition of this measure was claimed (Holthausen, 2009; Leuz, 2010) due to the incapacity of the law-on-the-books indexes to measure the national enforcer's activity level, both potential and actual, and not only the existence of the legal power to enforce. In this sense, the national enforcer's budget or its number of employees seemed to approximate input variables of the enforcement process (Coffee, 2007; Jackson \& Roe, 2009), such as the total national spending in audit fees (Hope, 2003). The total sanctions issued by the national enforcer (Jackson, 2007) are an attempt to measure the output of the same process.

A more recent contribution (Brown et al., 2014, used in Preiato et al., 2015) is of particular interest because it tries to get a more comprehensive view of the whole enforcement system with an index composed of both auditing system and national enforcer features. This index is more focused on the accounting enforcement and ranges from 0 to a maximum of 56, encompassing 51 countries. The audit system features for each country are static measures derived mainly from surveys of accountants' associations (FEE, IFAC) and include, for example, the existence of quality assurance program or ongoing professional development. The measures of the national enforcer effectiveness are both static (existence of specific activity, such as review of financial statements or power to set accounting and auditing standards), and dynamic (such as the level of resourcing or the existence of enforcement actions taken by the national enforcer).

It is worth to recall also a completely different approach to the measure of the enforcement system, which can be defined as an "indirect" approach, as it is based on the effects of low enforcement (Carvajal \& Elliott, 2009). In this sense, the magnitude of earnings management indexes (Daouk et al., 2006; DeFond et al., 2011; De George, 2015) existing in the different countries can surrogate a direct measure of the enforcement intensity.

Prior literature shows that the efforts to develop a specific measure of the accounting enforcement have been rapidly improving, but serious limitations continue to exist and methodological questions are still to be addressed. Empirical analyses still suffer for the lack of public data necessary to build dynamic measures. In the EU, for instance, the availability of databases of the public enforcement decisions is very limited, depending on the publicity regime existing in each member country. In this sense, it is very difficult to obtain the national enforcer's outputs, such as the number of decisions and the amount of sanctions issued. The input measures are difficult to get as well, and it is to recall that the traditional measures concern the resourcing of national enforcers at a general level, without a specific reference to the resources spent for the specific accounting enforcement activity.

A common choice for the scientific investigation is to conceive the enforcement as an activity performed by a single actor, typically the national enforcer, instead of a process involving the enforcers both at a firm-level (i.e. the auditors) and at a national level (i.e. the national enforcer agency). It is true that the role of the auditor in a strict sense is not to enforce company's behavior, because the auditor, differently from the national enforcer, has not the power to issue sanctions or to oblige companies to correct accounting errors. Auditors simply issue signals concerning accounting problems to shareholders and financial markets. The enforcement sanctions depending on the auditor activity will be the markets' and shareholders' reactions, such as dropping prices or substitution of CEO and other managers. However, it is a matter of fact that in the real world the national enforcer activity gets fundamental information inputs from the auditors' outputs to start its review, so we argue that the actual whole enforcement process has to deal with both the actors, namely company auditors and the national enforcer.

\section{The National Enforcer's Proactivity Ratio}

Prior studies paid particular attention to measure the differences in the enforcement systems between countries, while scant attention has been paid to measure the actual activity of national enforcers. Additionally, the relationship between the national enforcer and the auditors has not been investigated in depth yet.

In this study, we consider the enforcement as a process involving both the company auditors and the national enforcement agencies. In such a perspective, it is no wonder that auditors' opinions could anticipate the national enforcers' activity, with adverse or qualified opinions that could certainly be picked up as signals by the market, as well as any other enforcer's initiative undertaken when material misstatements are detected.

The national enforcers' selection process for monitoring companies, even if independent from auditors and normally based on published financial reports, could take auditors' opinion as a starting point. In this regard 
ESMA guidelines on enforcement of financial information (ESMA, 2014) require a selection model for enforcement activity based on a mixed model where a risk-based approach is combined with both a rotation and a random sampling approach, considering indications from the auditors as an extremely relevant information to trigger the selection itself. Furthermore, data gathered by external auditors can be useful to supervisors, and the EU Commission recognizes the need to strengthen cooperation between auditors and supervisory authorities even if any cooperation should not be allowed to blur the respective responsibilities (European Commission, 2010). Actually, the ESMA guidelines on enforcement require meetings with auditors and disclosure of matters to the bodies responsible for the audit as examples of examination procedures of an issuer's financial information.

Against this background, we focus on the proactive role of enforcers as monitoring bodies to understand to what extent the national enforcer's actions result from an autonomous activity or are driven by the auditors' reports. Auditors and national enforcers can be seen as parts of the same enforcement process, making it difficult to assess the actual and autonomous role played by each of them. In the light of these considerations, we conduct our analysis to evaluate and isolate the proactivity of national enforcers' actions respect to the activity performed by the auditors.

In pursuit of this objective, we investigate the actual monitoring process of the national enforcer shifting the focus to a deep analysis of national enforcers' actions by developing an index that proxies for the national enforcer's proactivity. Such index can be used as a measure to assess the effectiveness of the national enforcers, observed from a proactivity point of view, looking at their ability to detect unknown errors in its monitoring phase.

The index here proposed is designed also to help researchers to catch both the intensity and the effectiveness of a national enforcer, based on its own autonomous initiative, to allow a cross-country comparison. This kind of interpretation relies on the assumption that the behavior of auditors is more homogeneous compared to national enforcers, as the big audit firms share the same high-quality operating standards and as international organizations have incentives to develop and maintain uniform reputations around the world (Simunic and Stein, 1987). We posit this assumption considering the strong concentration of the audit market, especially in the European context (European Commission, 2010). Thus, the country differences in the enforcement intensity could be studied focusing on the actual actions triggered by the national enforcer.

Our national enforcer's proactivity index (NEP index) is developed taking simultaneously into consideration the outputs of the monitoring activity played by the auditors and the national enforcer. In particular, we adopt an output perspective focusing on audit opinions and on national enforcer's actions regarding the financial statements of the same company in a given year.

As a result, we obtain a classification that can be illustrated by a $2 \times 2$ matrix identifying four categories of companies (Figure 2): i) companies with modified auditors' opinions but that are not target of enforcement actions $(\alpha)$, ii) companies with both enforcement actions and modified opinions ( $\beta$ ), iii) companies that are target of enforcement actions but without any modified opinion $(\gamma)$, and $i v$ ) companies with unmodified opinion and that are not target of enforcement actions $(\delta)$. This classification combines the two levels of enforcement represented by auditors and national enforcers highlighting four possible cases.

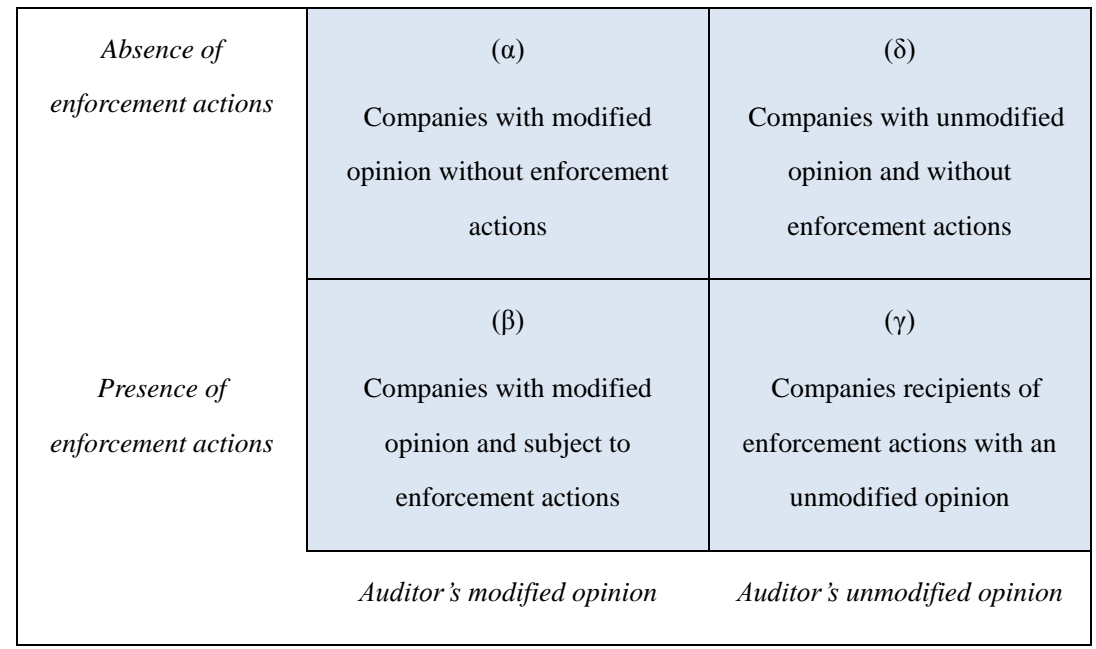

Figure 2. Classification of financial information's issuers 
If we consider the national enforcer's perspective, it distinguishes companies target of the enforcer's actions depending on the opinion received by the auditor. Companies belonging to the $\beta$ group have prepared financial statements with qualified opinions by auditors and have received enforcement actions. In this case, both the levels of enforcement have detected misstatements in the annual report and we can assume that the auditor's opinion has been an extremely relevant input for the national enforcer. On the other side, companies in the $\gamma$ group received enforcement actions that have not been preceded by a negative auditor's opinion. In this case, the national enforcer shows its proactivity in monitoring and identifying misstatements without receiving a public signal at the audit level.

Companies in groups $\alpha$ and $\delta$ have not received enforcement actions, but differ for the auditor's opinion. Auditors have issued a report highlighting some kind of misstatement for group $\alpha$, while declaring a IFRS compliance for financial statements prepared by group $\delta$. A plausible explanation for the existence of group $\alpha$ could lie in different levels of significance in the misstatement detection between national enforcers and auditors.

Nor the auditors or the national enforcer has found misstatements for companies in group $\delta$. In other words, the market has no signal of infringement by the two levels of the enforcement system. This group includes companies with annual reports actually compliant with IFRS and those for which the enforcement system was not able to detect any error. It is worth noting that, given the unmodified auditor's opinion, these companies might have been not directly checked by the national enforcer due to its sampling procedures.

The NEP index is based on this classification and empirically assesses the "real" and not the auditor-driven activity of national enforcers through the analysis of group $\gamma$, considering its relationship with the whole not compliant companies receiving an enforcement action $(\beta+\gamma)$. Thus, we compute the actual and unprompted intensity of national enforcement activities as follows:

$$
\text { NEP ratio }=\gamma /(\beta+\gamma)
$$

where:

$\gamma=$ number of firms obtaining enforcement actions but without modified opinions

$\beta=$ number of firms with modified opinions and obtaining enforcement actions

$\gamma+\beta=$ number of firms with infringement of IFRS framework.

The NEP ratio ranges from 0 to 1 and higher values of this index signal more proactive national enforcers. The maximum proactivity is reached when the NEP ratio equals 1 , as all the financial statements target of enforcement actions have been detected by the national enforcer without a modified auditor's opinion. On the contrary, a NEP ratio equal to 0 means that all financial statements with enforcement actions have already received a modified opinion by the auditor.

\section{Research Design}

To illustrate the potential of the NEP ratio for enforcement studies, we conduct an empirical analysis in an IFRS context. The investigation is based on the joint consideration of enforcement actions and of the auditors' reports regarding the same financial statements in order to identify which actions are the result of an autonomous monitoring activity by the national enforcer.

In particular, the exploratory analysis investigates all the enforcement actions by the German and the Italian enforcers regarding consolidated financial statements from the first year of IFRS mandatory adoption. Before explaining the construction of the NEP index, we briefly describe the characteristics of the German and Italian enforcement systems.

\subsection{The Enforcement Systems in Germany and Italy}

\subsubsection{The Two-Tier German Enforcement System}

The predominant characteristic of the enforcement system in Germany is its two-tier structure (Ernstberger et al., 2012), which involves a private institution (the DPR, Deutsche Prüfstelle für Rechnungslegung) and a federal agency (the Bundesanstalt für Finanzdienstleistungsaufsicht - BaFin) that represents the public German enforcer. The first tier involves the DPR Enforcement Panel, as its active body. In the second tier, the Bafin participates in the enforcement process to determine whether an error has occurred when the DPR opinion differs from that of the company, to order the publication of discovered errors, or to perform an examination with sovereign means when a company is not willing to cooperate with the Panel (DPR, 2005). The goal of the enforcement process is to assess the compliance with the relevant accounting principles of recent individual and consolidated financial statements (and their related management reports) of firms listed on regulated markets on domestic stock exchanges. 
At the first tier, the Panel can initiate an examination if there are concrete indications of an infringement of financial reporting requirements or following a request of the BaFin. The Panel can also initiate an examination without any indications of an infringement, through a systematic sampling. For this kind of examinations, the Panel uses a combination of random-based and risk-based selection procedures, according to the selection methods admitted by the ESMA Guidelines (ESMA, 2014). The sole assignment of the DPR is to conclude whether the financial statement is erroneous. Because the DPR is a private body without an authoritative power to oblige companies, the Panel only examines the financial statements if the firm under investigation is willing to cooperate; in other words, if the company declares its willingness to cooperate, the legal representatives of the firm (or other persons) are obliged to provide the additional information requested by the DPR. In absence of willingness to cooperate, the DPR notifies BaFin of this situation; in this case, the BaFin will order an examination at the second-tier level. After the examination of the documents, the DPR decides whether the financial statements are erroneous. If the DPR establishes material errors, companies have a sufficient time to decide whether they agree with the DPR findings.

The second tier involves only the BaFin, which initiate an investigation when a firm does not cooperate with the DPR or when the management does not agree completely or partially with the DPR findings (in the case that DPR discovers material errors in the financial statements). However, the most important task of BaFin is to enforce the disclosure of error findings. When erroneous accounting is detected by DPR or by BaFin, BaFin requires companies to disclose these error findings in a press release. These press releases are broadcasted via the electronic platform of the Federal Gazette (the Elektronischer Bundesanzeiger).

The objective of this enforcement system is to achieve compliance of the financial statements through the adverse disclosure. This "name and shame" publicity relies on investor reactions to published error findings. Thus, the only sanction for infringing companies is the negative market reaction, the deterrent for managers to misstate the accounts (Hitz et al., 2012).

\subsubsection{The Italian Enforcement System}

The Italian enforcement system for listed companies involves only a public enforcer (the Commissione Nazionale per le Società e la Borsa, CONSOB). The main difference from the German system is that there is only one public enforcer that supervises the compliance with the relevant accounting principles of individual and consolidated financial statements. CONSOB can initiate an examination if there is evidence of an infringement of financial reporting requirements (i.e. from a trial in progress) and, like DPR, it also selects firms to examine through a systematic sampling.

In the Italian context, the Legislative Decree n. 58 of 1998 (commonly known as the Testo Unico della Finanza TUF) and the incorporation into the Italian Law of the European Transparency Directive (with the Legislative Decree n. 195 of 2007) reformed the regulation of financial markets. Following these reforms, CONSOB can choose between two accounting enforcement actions: the impugnativa di bilancio (challenge procedure) ex article 157 of TUF and the accertamento di non conformità (non-compliance procedure) ex article 154-ter of TUF.

In case of impugnativa di bilancio, CONSOB can challenge a shareholders' meeting resolution approving the annual accounts on the grounds that these accounts do not comply with the relevant financial reporting framework. the Authority can take this action up to six months after the filing of consolidated or annual accounts. With this action, CONSOB can request the courts to verify the conformity of accounts; in particular, the courts may declare null and void the shareholders' meeting resolution and can require a reissuance of the erroneous financial statements. In case of accertamento di non conformità, CONSOB discovers material errors in the annual or half-year financial report of a firm and require it to disclose a correction of the financial report. In particular, CONSOB can require a corrective note and/or a correction in future financial statements with the restatement of comparatives in order to ensure an accurate information compliant with relevant accounting principles. CONSOB states that it uses first the accertamento di non conformità and the impugnativa di bilancio only for residual cases (CONSOB, 2009). In its 2009 annual report, CONSOB specifies that it uses the impugnativa di bilancio only for particular deficit cases, or when the firm does not agree with a previous accertamento di non conformità or when a firm repeats the error, previously discovered by an accertamento di non conformità in the following financial report. Indeed, from 2009 to 2015 CONSOB used in only 5 cases the impugnativa di bilancio and, instead, it has enforced the compliance of financial statements in 18 cases through the accertamento di non conformità.

The CONSOB publicity regime is different from the DPR one: information concerning errors findings are available on the corporate website, on the CONSOB electronic platform (the "Bollettino Elettronico") or in the annual reports of the Authority. 


\subsection{Data Collection and Analysis}

Our analysis focuses on consolidated financial statements by Italian and German listed companies from 2005 to 2014. To develop our index, we first collect data to identify which financial statements have received enforcement actions by national enforcers in the aforementioned time horizon. We use public information regarding enforcement actions, available on national enforcers' websites. We acknowledge that our index, based solely on public information, does not capture other possible private communications. In fact, an exchange of information between public enforcers and auditors/firms that it is not publicized could be supposed. However, we think that public data sources are important to ensure that our index can be implemented in many countries to allow cross-country analyses.

To build the NEP index, we analyze all the erroneous consolidated statements discovered by the German and Italian public enforcers. In particular, we investigate all the enforcement releases published on the electronic platform of the Federal Gazette for the German system. Table 1 reports the sample selection of the German errors findings related to consolidated statements.

Table 1. The auditors' opinions for financial statements with enforcement actions

\begin{tabular}{lc}
\hline & No. \\
\hline Initial errors findings & 166 \\
Rephrased versions of earlier error findings & 12 \\
Unavailability of auditors'opinion & 14 \\
\hline Final observations & 140 \\
\hline
\end{tabular}

As highlighted in Table 1, this search leads to an initial sample of 166 erroneous consolidated statements. First, we eliminate 12 observations that represent rephrased versions of earlier error findings, and then we hand-collect all the related auditors' opinions. Finally, we eliminate 14 statements for the unavailability of auditors' opinion, resulting in a sample of 140 observations.

In the same way, we investigate all the CONSOB enforcement actions regarding consolidated statements for the Italian enforcement system. In this case, we use the CONSOB electronic platform (bollettino elettronico) and every annual report of the Authority. The initial sample consists in 27 erroneous statements. Then we eliminate 2 impugnativa di bilancio that enforce the same statement of an earlier accertamento di non conformità and we collect the related auditors' opinion, thus obtaining a sample of 25 observations (17 accertamenti and 8 impugnative).

Based on those data, we determine how many companies form the groups $\beta$ (misstatements detected by both auditor and national enforcer) and $\gamma$ (misstatements detected only by the national enforcer) for each country in every year of the observation period. This analysis is conducted for each financial statement target of at least an enforcement action by the national enforcer.

To compute how many financial statements are part of group $\beta$, we consider as signals of possible misreporting all the modified auditors' opinions. In particular, according to ISA 705, auditors shall modify their opinion when they conclude that, based on the evidence obtained, the financial statements are materially misstated or when they are unable to obtain appropriate evidence to conclude that the financial statements are free from material misstatement. Those data are used to compute the NEP ratio for both countries according to the aforementioned formula.

Additionally, we determine a comprehensive NEP ratio considering as a signal of possible misreporting by auditors not only the modified opinions as defined by the ISA 705, but also the unmodified opinion with Emphasis of Matter Paragraph. Auditors, according to ISA 706, shall include an Emphasis of Matter Paragraph to draw users' attention to a matter disclosed in the financial statements, that is fundamental to users' understanding of the statements. For example, auditor may decide to include an Emphasis of Matter Paragraph when exists an uncertainty relating to the future outcome of exceptional litigation or regulatory action.

\section{Results}

To analyze the nature of the Italian and German national enforcement system, first, we present data on enforcement actions and auditors' opinions. To determine the NEP ratio, we consider as a signal of possible misreporting the qualified opinion, the adverse opinion and the disclaimer of opinion, all the types of modified opinion as defined by the ISA 705. In particular, the auditor expresses an adverse opinion when the evidence obtained leads the auditor to conclude that the misstatements are both material and pervasive. The auditors, 
instead, qualify the opinion when the misstatements are material but not pervasive. Additionally, auditors express a qualified opinion when they are unable to obtain appropriate and sufficient evidence to conclude whether misstatements exist and the possible effects of undetected errors on financial statements can be material but not pervasive. Furthermore, auditors disclaim an opinion when they are unable to obtain sufficient evidence and they conclude that the possible effects of undetected errors can be material and pervasive. Table 2 reports the different types of auditors' opinions related to the erroneous consolidated statements for both countries.

Table 2. The auditors' opinions for financial statements with enforcement actions

\begin{tabular}{lcc}
\hline & Italy & Germany \\
\hline Adverse opinion & 1 & 1 \\
Qualified opinion & 2 & 13 \\
Disclaimer of opinion & 3 & 1 \\
Unmodified opinion & 19 & 125 \\
\hline Total & 25 & 140 \\
\hline
\end{tabular}

It is arguably to note that there is a lack of uniformity between the national enforcer actions and the auditors' reports, in fact for only 20 statements on 165 observations the auditors modify their opinion. In particular, auditors highlight a material misstatement for only 17 cases (adverse and qualified opinions) and they conclude in 144 cases that the financial statements are free from material misstatement. Based on these data, we estimate the national enforcement proactivity ratio (NEP ratio). Table 3 reports the number of erroneous consolidated statements, the related unmodified opinions and the estimation of the NEP index for the period of analysis 2005-2014.

Table 3. The NEP ratio

\begin{tabular}{|c|c|c|c|c|c|c|}
\hline $\begin{array}{l}\text { Year } \\
\text { (consolidated } \\
\text { statements) }\end{array}$ & $\begin{array}{c}\text { Italy } \\
\boldsymbol{\beta}\end{array}$ & $\begin{array}{c}\text { Italy } \\
\gamma\end{array}$ & $\begin{array}{c}\text { Italy } \\
\text { NEP ratio }\end{array}$ & $\begin{array}{c}\text { Germany } \\
\boldsymbol{\beta}\end{array}$ & $\begin{array}{c}\text { Germany } \\
\gamma\end{array}$ & $\begin{array}{c}\text { Germany } \\
\text { NEP } \\
\text { ratio }\end{array}$ \\
\hline 2005 & 0 & 1 & & 5 & 20 & \\
\hline 2006 & 1 & 1 & & 1 & 28 & \\
\hline 2007 & 0 & 3 & & 2 & 11 & \\
\hline 2008 & 1 & 2 & & 2 & 18 & \\
\hline 2009 & 1 & 0 & & 2 & 17 & \\
\hline 2010 & 0 & 0 & & 2 & 9 & \\
\hline 2011 & 3 & 6 & & 1 & 8 & \\
\hline 2012 & 0 & 5 & & 0 & 11 & \\
\hline 2013 & 0 & 0 & & 0 & 3 & \\
\hline 2014 & 0 & 1 & & 0 & 0 & \\
\hline Total & 6 & 19 & $76.00 \%$ & 15 & 125 & $89.29 \%$ \\
\hline
\end{tabular}

The trend of the German enforcement system is different from the Italian one, in particular the number of German erroneous statements decreases over time. This is due probably to the introduction of the two-tier system that has increased the likelihood of detecting companies that issue inaccurate financial statements and, consequently, managers are more discouraged to misstate the financial reports (Ernstberger et al., 2012; Böcking et al., 2015).

For the Italian enforcement system, instead, it seems that the number of enforcement actions is increased after the introduction of the accertamento di non conformità in 2007. As highlighted in Table 3, during the time horizon under investigation CONSOB is more reactive than DPR: its enforcement actions are preceded by an unmodified auditor's opinion in $76 \%$ of cases against the $89.29 \%$ of the German public enforcers.

Then, we also determine a comprehensive NEP ratio considering as a signal of possible misreporting not only the modified opinions as defined by the ISA 705, but also the unmodified opinion with Emphasis of Matter Paragraph. According to ISA 706, auditors shall include an Emphasis of Matter Paragraph to draw users' attention to a matter disclosed in the financial statements that is fundamental to users' understanding of the statements. For example, an auditor can decide to include an Emphasis of Matter Paragraph when an uncertainty relating to the future outcome of exceptional litigation or regulatory action exists. Table 4 reports the different 
types of auditors' opinion related to the erroneous consolidated statements for both countries. In particular, the Table draws attention to the modified opinions with Emphasis of Matter Paragraphs.

Table 4. The auditors' opinions for financial statements with enforcement actions

\begin{tabular}{|c|c|c|}
\hline & Italy & Germany \\
\hline $\begin{array}{l}\text { Modified opinion (sum of adverse, qualified and } \\
\text { disclaimer) }\end{array}$ & 6 & 15 \\
\hline $\begin{array}{l}\text { Unmodified opinion with Emphasis of Matter } \\
\text { Paragraphs }\end{array}$ & 14 & 17 \\
\hline Unmodified opinion (clean opinion) & 5 & 108 \\
\hline Total & 25 & 140 \\
\hline
\end{tabular}

Considering as a signal of possible misreporting also the unmodified opinions with Emphasis Paragraphs, the number of unmodified opinions without any signal of possible misreporting decreases. In particular, the clean opinions for Italy become only 5, that are equal to about a quarter of those reported in the first-level analysis (Table 1). The German clean opinions decrease less than the Italian ones, from 125 (Table 1) to 108.

Based on these data, we estimate the comprehensive NEP ratio, determined by dividing the number of firms obtaining enforcement actions but without modified opinions or unmodified opinions with Emphasis Paragraph $\left(\gamma^{*}\right)$ by the number of firms with infringement of IFRS framework discovered by national enforcers $\left(\beta^{*+} \gamma^{*}\right)$, which also include the number of firms with modified opinions or opinions with Emphasis Paragraph and obtaining enforcement actions $\left(\beta^{*}\right)$. Table 5 reports the number of erroneous consolidated statements, the related clean opinions and the estimation of the comprehensive NEP ratio for the period of analysis 2005-2014.

Table 5. The comprehensive NEP ratio

\begin{tabular}{lcccccc}
\hline $\begin{array}{l}\text { Year of the } \\
\text { consolidated } \\
\text { statements }\end{array}$ & $\begin{array}{c}\text { Italy } \\
\beta^{*}\end{array}$ & $\begin{array}{c}\text { Italy } \\
\gamma^{*}\end{array}$ & $\begin{array}{c}\text { Italy Compr. } \\
\text { NEP ratio }\end{array}$ & $\begin{array}{c}\text { Germany } \\
\beta^{*}\end{array}$ & $\begin{array}{c}\text { Germany } \\
\gamma^{*}\end{array}$ & $\begin{array}{c}\text { Germany } \\
\text { ComprNEP } \\
\text { ratio }\end{array}$ \\
\hline 2005 & 1 & 0 & & 6 & 19 & \\
2006 & 1 & 1 & & 5 & 24 & \\
2007 & 3 & 0 & & 5 & 8 & \\
2008 & 2 & 1 & 6 & 14 & \\
2009 & 1 & 0 & 5 & 14 & \\
2010 & 0 & 0 & 2 & 9 & \\
2011 & 7 & 2 & 1 & 8 & \\
2012 & 4 & 1 & & 2 & 9 & \\
2013 & 0 & 0 & & 0 & 3 & \\
2014 & 1 & 0 & & 0 & 0 & \\
\hline Total & 20 & 5 & $20.00 \%$ & 32 & 108 & $77.14 \%$ \\
\hline
\end{tabular}

Table 5 shows that, considering the unmodified with Emphasis Paragraph as a signal of possible misreporting, CONSOB is even more reactive than the German public enforcers. In this case, the Italian enforcement actions are not preceded by auditors' opinion that may highlight a situation of possible misreporting (modified opinion and opinion with Emphasis Paragraph) in only 5 cases. In particular, the Italian comprehensive NEP ratio (20\%) is equal to about a quarter of the German one (77.14\%).

\section{Conclusions}

This paper examines the accounting enforcement as a complex system, in which not only national enforcers but also other subjects operate as substantial enforcers, namely the auditors. This system is investigated according to this perspective, shifting the focus from the national enforcer alone to the unexplored link between this authority and auditors.

This is the starting point to develop an index (NEP ratio) capturing the intensity of national enforcement as the proactivity of the national enforcer in identifying accounting infringements not detected by auditors. While prior literature often adopts static measures based on inputs (e.g. resources devoted to enforcement), this index is a dynamic proxy capturing the original output of national enforcers' activity. It can help to advance our understanding of the role of national enforcers by observing to what extent they are able to detect errors not already discovered by auditors. Additionally, this measure could be of great interest especially for cross-country 
analyses as it can represent a proxy for the effectiveness of a national enforcer's activity.

An illustrative empirical analysis is conducted in an IFRS context to show the potential of the index for enforcement studies. In particular, the exploratory analysis investigates all the enforcement actions by the German and the Italian enforcers regarding consolidated financial statements from the first year of IFRS mandatory adoption. The investigation is based on the joint consideration of those actions and on the auditors' reports regarding the same financial statements to identify which actions are the result of an autonomous monitoring activity by the national enforcer. The resulting NEP ratio is determined as the percentage of financial statements receiving an enforcement action without any previous public signal by auditors on the overall number of financial statements target of enforcement actions.

Findings highlight a different degree of proactivity between the Italian and the German enforcers, with a higher ability of the German ones to conduct autonomous analyses resulting in enforcement actions. On the contrary, empirical evidence suggests that the Italian authority is more reactive in monitoring listed companies, relying more on auditors' opinions instead of pursuing new investigations. These results might depend on different procedures adopted in the two national contexts, such as the sampling decisions taken or the risk approach actually followed, that can be different even if consistent with the common ESMA guidelines.

Exploratory findings illustrate how the NEP ratio can be used to compare the intensity of enforcement by different national enforcers, also in the light of these considerations. The proactivity of a national enforcer, in other words, can be seen as a proxy for enforcement effectiveness under the assumption that the monitoring activity performed by auditors is less affected by country differences.

The analysis of the output of national enforcers also highlights the scarcity of public data regarding the activity of different players involved in the accounting enforcement process. This issue refers to national enforcers' and auditors' activity in different ways. Data on monitoring procedures adopted by national enforcers, for instance, are rarely disclosed, thus limiting scholars' possibility of cross-country comparisons. Auditors' opinions, on the contrary, are publicly available within companies' financial statements, but in most countries outside the US a single public or a private repository does not exist. This means that empirical analyses on the topic must rely on indirect measures or on hand-collection of data that are formally public, but actually very difficult to collect for representative samples.

This opacity is particularly striking given the role played by national enforcers that should ensure compliance and transparency for the financial markets. Additionally, this point stresses the demand for more cooperation between accounting scholars, legislators, and regulators, as better economic analyses need the necessary data that could be efficiently collected by regulators and authorities (Leuz \& Wysocki, 2016).

This study informs the current debate on accounting enforcement by broadening the scope of the analysis from the activity of the national enforcer as a stand-alone subject to encompass the signals that it receives from another "substantial" enforcer, namely the auditor.

Against this background, it extends the prior literature by proposing an index based on the output of national enforcers, measuring their proactivity with respect to auditors' opinions. This enforcement measure can support future research in two possible directions. First, it can be used to explore national enforcers' activity focusing on the role played by these subjects in the complex enforcement system, identifying their proactivity in identifying accounting infringements. Second, it represents an alternative measure for national enforcement intensity capturing the additional output of national enforcers and not simply its input - to be adopted in cross-country studies on accounting quality. In this perspective, it can support future research on the value relevance of enforcement actions and on the association between enforcement and earnings management.

\section{References}

Armstrong, C., Barth, M., Jagolinzer, A., \& Riedl, E. (2010). Market reaction to the adoption of IFRS in Europe. The Accounting Review, 85, 31-61. https://doi.org/10.2308/accr.2010.85.1.31

Ball, R., Kothari, S. P., \& Robin, A. (2000). The Effect of International Institutional Factors of Properties of Accounting Earnings. Journal of Accounting and Economics, 29, 1-51. https://doi.org/10.1016/S0165-4101(00)00012-4

Ball, R., Robin, A., \& Wu, J. S. (2003). Incentives versus Standards: properties of accounting income in four East Asian countries. Journal of Accounting and Economics, 36, 235-270. https://doi.org/10.1016/j.jacceco.2003.10.003

Böcking, H. J., Gros, M., \& Worret, D. (2015). Enforcement of accounting standards: how effective is the 
German two-tier system in detecting earnings management? Review of Managerial Science, 9(3), 431-485. https://doi.org/10.1007/s11846-014-0159-z

Brown, P., Preiato, J, \& Tarca, A. (2014). Measuring Country Differences in Enforcement of Accounting Standards: An Audit and Enforcement Proxy. Journal of Business Finance \& Accounting, 41(1-2), 1-52. https://doi.org/10.1111/jbfa.12066

Byard, D., Li, Y., \& Yu, Y. (2011). The Effect of Mandatory IFRS Adoption on Financial Analysts' Information Environment. Journal of Accounting Research, 49(1), 69-96. https://doi.org/10.1111/j.1475-679X.2010.00390.x

Cai, L., Rahman, A. R., \& Courtenay, S. M. (2008). The effect of IFRS and its enforcement on earnings management: An international comparison. Available at SSRN 1473571. https://doi.org/10.2139/ssrn.1473571

Carvajal, A., \& Elliott, J. (2009). The Challenge of Enforcement in Securities Markets. Mission Impossible? Policy paper WP/09/168 (New York: International Monetary Fund).

CESR (2007). CESR's review of the implementation and enforcement of IFRS in the EU. Retrieved from https://www.esma.europa.eu/document/cesr\%E2\%80\%99s-review-implementation-and-enforcement-ifrs-ineu

Chen, C. J., Su X., \& Zhao R. (2000). An Emerging Market's Reaction to Initial Modified Audit Opinions: Evidence from the Shanghai Stock Exchange. Contemporary Accounting Research, 17(3), 429-455. https://doi.org/10.1506/GCJP-5599-QUWB-G86D

Christensen, H. B., Hail, L., \& Leuz, C. (2013). Mandatory IFRS reporting and changes in enforcement. Journal of Accounting and Economics, 56(2), 147-177. https://doi.org/10.1016/j.jacceco.2013.10.007

Coffee, J. C. Jr. (2007). Law and the Market: The Impact of Enforcement. Columbia Law and Economics Working Paper, No. 304. https://doi.org/10.2139/ssrn.967482

CONSOB (2009). Annual report.

Daouk, H, Lee, C. M. C., \& Ng, D. T. (2006). Capital Market Governance: How Do Securities Laws Affect Market Performance? Journal of Corporate Finance, 12(3), 560-593. https://doi.org/10.1016/j.jcorpfin.2005.03.003

Daske, H., Hail, L., Leuz, C., \& Verdi, R. (2008). Mandatory IFRS reporting around the world: Early evidence on the economic consequences, Journal of Accounting Research, 46(5), 1085-1142.

De George, E. T. (2015). Accounting Harmonization and Equity Market Contagion. Working Paper.

DeFond, M. L., Hu, X., Hung, M., \& Li, S. (2011). The impact of mandatory IFRS adoption on foreign mutual fund ownership: The role of comparability. Journal of Accounting and Economics, 51, 240-258. https://doi.org/10.1016/j.jacceco.2011.02.001

Demmer, M., Pronobis, P., \& Yohn, T. (2015). Financial Statement-Based Forecasts and Analyst Forecasts of Profitability: The Effect of Mandatory IFRS Adoption. Available at SSRN 2544566. https://doi.org/10.2139/ssrn.2544566

Djankov, S., La Porta, R., Lopez-de-Silanes, F., \& Shleifer, A. (2008). The Law and Economics of Self-Dealing. Journal of Financial Economics, 88(3), 430-465. https://doi.org/10.1016/j.jfineco.2007.02.007

DPR (2005), Code of procedures of enforcement panel. Available at: www.frep.info.

Ernstberger, J., Stich, M., \& Vogler, O. (2012). Economic consequences of accounting enforcement reforms: the case of Germany. European accounting review, 21(2), 217-251.

https://doi.org/10.1080/09638180.2011.628096

ESMA (2014). ESMA guidelines on enforcement of financial information.

European Commission (2010). Green paper: Audit policy: Lessons from the crisis. Publications Office of the European Union.

Fédération des Experts Comptables Européens (FEE) (2001). "Enforcement mechanisms in europe-a preliminary investigation of oversight systems".

Florou, A, \& Pope, P. F. (2012) Mandatory IFRS Adoption and Institutional Investment Decisions. The Accounting Review, 87(6), 1993-2025. https://doi.org/10.2308/accr-50225 
Glaum, M., Schmidt, P., Street, D. L., \& Vogel, S. (2013). Compliance with IFRS 3- and IAS 36-required disclosures across 17 European countries: company and country-level determinants. Accounting and Business Research, 43(3), 163-204. https://doi.org/10.1080/00014788.2012.711131

Gros, M., \& Koch, S. (2015). Goodwill Impairment Test Disclosures Under IAS 36: Disclosure Quality and its Determinants in Europe. Available at SSRN 2636792. https://doi.org/10.2139/ssrn.2636792

Hitz, J. M., Ernstberger, J., \& Stich, M. (2012). Enforcement of accounting standards in Europe: Capital-market-based evidence for the two-tier mechanism in Germany. European accounting review, 21(2), 253-281. https://doi.org/10.1080/09638180.2011.641727

Holthausen, R. W. (2009). Accounting Standards, Financial Reporting Outcomes, and Enforcement. Journal of Accounting Research, 47, 447-458. https://doi.org/10.1111/j.1475-679X.2009.00330.x

Hope, O. K. (2003). Disclosure practices, enforcement of accounting standards, and analysts' forecast accuracy: an international study. Journal of Accounting Research, 41(2), 235-272. https://doi.org/10.1111/1475-679X.00102

Houqe, N., van Zijl, T., Dunstan, K., \& Waresul Karim, A. K. M. (2012). The effect of investor protection and IFRS adoption on earnings quality around the world. The International Journal of Accounting, 47(3), 333-355. https://doi.org/10.1016/j.intacc.2012.07.003

Jackson, H. (2007). Variation in the intensity of financial regulation: Preliminary evidence and potential implications. Yale Journal on Regulation, 24, 253-291.

Jackson, H., \& Roe, M. (2009). Public and private enforcement of securities laws: resource-based evidence. Journal of Financial Economics, 93(2), 207-238. https://doi.org/10.1016/j.jfineco.2008.08.006

Kaufmann, D., Kraay, A., \& Mastruzzi, M. (2011). The worldwide governance indicators: methodology and analytical issues. Hague Journal on the Rule of Law, 3(2), 220-246. https://doi.org/10.1017/S1876404511200046

La Porta, R., Lopez-De-Silanes, F., \& Shleifer, A. (2006). What Works in Securities Laws. Journal of Finance, 61(1), 1-36. https://doi.org/10.1111/j.1540-6261.2006.00828.x

La Porta, R., Lopez-De-Silanes, F., Shleifer, A., \& Vishny, R. W. (1997). Legal Determinants of External Finance. The Journal of Finance, 52(3), 1131-1150. https://doi.org/10.1111/j.1540-6261.1997.tb02727.x

La Porta, R., Lopez-De-Silanes, F., Shleifer, A., \& Vishny, R. W. (1998). Law and finance. Journal of Political Economy, 106(6), 1113-1155. https://doi.org/10.1086/250042

Landsman, W. R., Maydew, E. L., \& Thornock, J. R. (2012). The information content of annual earnings announcements and mandatory adoption of IFRS.Journal of Accounting and Economics, 53(1), 34-54. https://doi.org/10.1016/j.jacceco.2011.04.002

Leuz, C. (2010). Different approaches to corporate reporting regulation: how jurisdictions differ and why, Accounting and Business Research, 40(3), 229-256. https://doi.org/10.1080/00014788.2010.9663398

Leuz, C., \& Wysocki, P. D. (2016). The economics of disclosure and financial reporting regulation: evidence and suggestions for future research. Journal of Accounting Research, 54(2), 525-622. https://doi.org/10.1111/1475-679X.12115

Leuz, C., Nanda, D., \& Wysocki, P. (2003). Earnings management and investor protection: An international comparison. Journal of Financial Economics, 69(3), 505-527. https://doi.org/10.1016/S0304-405X(03)00121-1

Li, S. (2010). Does Mandatory Adoption of International Financial Reporting Standards in the European Union Reduce the Cost of Equity Capital? The Accounting Review, 85(2), 607-636. https://doi.org/10.2308/accr.2010.85.2.607

Menon, K., \& Williams, D. D. (2010). Investor reaction to going concern audit reports. The Accounting Review, 85(6), 2075-2105. https://doi.org/10.2308/accr.2010.85.6.2075

Pownall, G., \& Wieczynska, M. (2013). Deviations from the Mandatory Adoption of IFRS in the European Union: Implementation, Enforcement, Incentives, and Compliance. Available at SSRN 1919805.

Preiato, J., Brown, P., \& Tarca, A. (2015). A Comparison of Between-Country Measures of Legal Setting and Enforcement of Accounting Standards. Journal of Business Finance \& Accounting, 42(1-2), 1-50. https://doi.org/10.1111/jbfa.12112 
Quagli, A., \& Ramassa, P. (2017). L'enforcement dell'informativa contabile. Turin: Giappichelli.

Silvers, R. (2013). The Effect of Enforcement on the Market Capitalization of Earnings: Evidence from U.S. Foreign Filers. Working paper.

Simunic, D. A., \& Stein, M. T. (1987). Product differentiation in auditing: Auditor choice in the market for unseasoned new issues (No. 13). Canadian Certified General.

Van Beest, F., Litjens, R., \& Vergoossen, R. (2013). Financial Reporting Enforcement and Mandatory IFRS Disclosures. Working Paper.

\section{Copyrights}

Copyright for this article is retained by the author(s), with first publication rights granted to the journal.

This is an open-access article distributed under the terms and conditions of the Creative Commons Attribution license (http://creativecommons.org/licenses/by/4.0/). 